\title{
Catherine Diamond
}

\section{Being Carmen: Cutting Pathways towards Female Androgyny in Japan and India}

In this article Catherine Diamond examines the flows of transcultural hybridity occurring in dance between Spanish flamencos, Japanese exponents of flamenco, and Indian dancers interacting with flamenco within their classical dance forms. Japan and India represent two distinct Asian reactions to the phenomenon of global flamenco: the Japanese have adopted it wholesale and compete with the Spanish on their own ground; the Indians claim that as the Roma (gypsy) people originated in India, the country is also the home of flamenco. Despite their differing attitudes, flamenco dance offers women in both cultures a pathway toward participating in an internal androgyny, a wider spectrum of gender representation than either the Asian traditional dance or contemporary Asian society normally allows. Catherine Diamond is a professor of theatre and environmental literature. She is Director of the Kinnari Ecological Theatre Project in Southeast Asia, and the director/choreographer of Red Shoes Dance Theatre in Taiwan.

Key terms: flamenco, kathak, Kalbeliya, androgyny, transcultural hybridity, Gitano aesthetics.

SHE IS INDEPENDENT, defiant, beautiful, sensuous, talented, freedom-loving, humorous, intelligent, and resourceful - what is there not to like about Carmen? The iconic gypsy woman personifies the ambiguous seduction and threat of her 'exotic race'. She aggressively accosts her military captor, cavalierly drops him to flaunt her love for a picador, takes up with an outlaw, then bravely faces death at the hands of her former lover, and is from beginning to end a fanciful creation of two French men - Prosper Mérimée, who wrote the novel, and Georges Bizet who composed what is now the world's most popular opera. ${ }^{1}$

Though much demeaned as a commercialized femme fatale cliché, her story nonetheless endures. Carmen haunts the city of Sevilla, where she was among the first Spanish women earning independent livelihoods in the tabacalera, the tobacco factory. Because of tourist attraction to her story, a rather pathetic statue was erected opposite the Plaza de Toros, but she has far more ardent devotees in the thousands of women dedicated to the music and dance of flamenco, the
Andalusian Gitano contribution to world cultural heritage. $^{2}$

Many come from Asia - Korea, Taiwan, the Philippines, Hong Kong, Singapore and, increasingly, China - but by far the largest number is from Japan. Since the 1980 Japan has hosted the second greatest number of flamenco practitioners outside Spain. Not only do the 80,000 adherents support a vibrant flamenco subculture, but they increasingly win commendation in Spain for their artistry. ${ }^{3}$ From being mere curiosities in the Madrid and Sevilla dance studios, they now make up half the audience at major flamenco festivals and are a primary financial force that sustains Spanish artists in economic hard times. ${ }^{4}$ India, with its spectacular dance tradition, has evinced little interest in learning flamenco music and dance. Two female beginners who have opened studios in Mumbai, and a male Bollywood dancer are currently the flamenco 'scene'. Instead, flamenco has become a familiar contributor to Indian dance's own transcultural identity.

Flamenco has an important presence in the two Asian cultures - Japan being the first 
Asian country to adopt flamenco and make it an unusually popular vocation and avocation as well as cultivating it as an internal touristic attraction, evidenced in the Parque España theme park. In contrast, India is touted as the 'home' of flamenco because it is the likely origin of the Roma (gypsies), who, making up one of many of Rajasthan's musician castes, migrated from north India across Europe, arriving in Spain in $1425 .{ }^{5}$

Flamenco's following in Japan is primarily a private affair driven by personal motivation to study locally and abroad, set up tablaos (bars for flamenco performance), and invite Spanish artists to perform. In India, flamenco's presence has been stimulated mostly by Indian and Spanish cultural bureaucrats and 'folklorist-managers' who collaborate in sponsoring bicultural events featuring musicians and dancers from both traditions. ${ }^{6}$ They stress the cultural links and aesthetic affinities of flamenco and Indian dance, particularly kathak and Kalbeliya dance, culminating in 2014 with the launching of the Jodhpur Flamenco and Gypsy Festival. Featured artists from both countries partake in various kinds of music and dance collaborations to demonstrate the readily apparent commonalities, but they approach each other with differing intention. ${ }^{7}$

\section{The Global Phenomenon}

The relationships of both Japan and India to flamenco, however, are built on rather mysterious and contested affinities. Flamenco is the art of the Gitanos, a persecuted ethnic minority, and expresses communal anguish and protest, as well as individual despair and joy. Japanese culture is perceived as being very different, even opposite. To flamencos, the Japanese are the epitome of a cool dispassionate race and their culture opaque with its highly codified gestures in the observance of which propriety represses emotion to preserve a calm exterior of social harmony.

Yet Japanese flamenco practitioners claim a deep cultural affinity in the tension created by the social repression of individual emotion and the oppression of Gitanos in Spanish society, allowing the Japanese a legitimate outlet for the expression of passion in flamenco. The converse occurs in India, for both Gitano and Indian dancers claim that the technical similarities such as the rhythmic footwork and the carriage of the arms demonstrate a genealogical link. Not only do several historical factors contradict this claim and point to other possible reasons for the similarities, but also there are no substantiated connections between classical kathak and the dance performed by Kalbeliya women, despite the two being the most associated with flamenco. The dubious commonality of origins becomes less important than what evolved separately over centuries. The historical convergences remain mostly conjectural, and the three forms today are profoundly dissimilar in tone, intent, meaning, and temperament, as Miriam Phillips asserts:

They [flamenco and kathak] also have some very real differences - technically, musically, visually, aesthetically, expressively, and experientially. . . . In fact, mapping these differences to each dance form's particular history reveals how dance can be understood as an embodiment of culture - a manifestation of a culture's particular ethos, values, and aesthetics. ${ }^{8}$

Although both artists and governments continue to embark on intercultural collaborations built upon the obvious similarities and ostensible historical connections, this inquiry investigates the significant differences between Indian dance and flamenco, differences that perhaps also help to explain flamenco's particular attraction for Japanese women.

In the twenty-first century, Japanese women face contradictions in their status and self-image within society. Many are collegeeducated and financially independent but still sense gender discrimination. And although they also enjoy Latin dances such as tango and salsa, flamenco offers them something distinct because it is not a social dance but a solo dance, and a woman does not have to follow a male partner. The Japanese appear to have adopted the European nineteenth-century 'neo-exotic' fascination with Gitano culture, when Spain (because of its long Arabic rule) was where Europe ended and the 'East' began. 


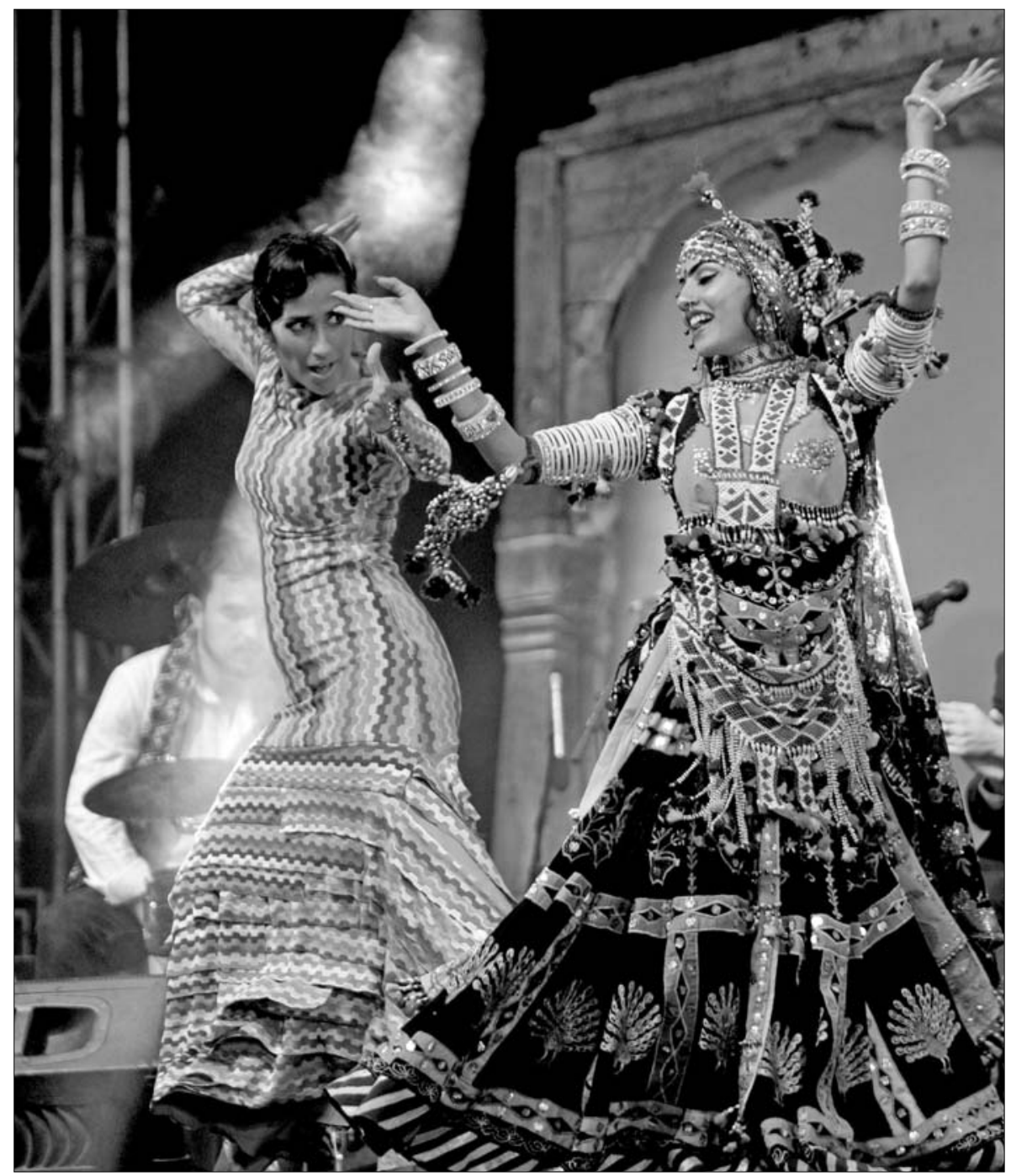

Flamenco and Kalbeliya performers pair up to show the common features of their music and dance at the Jodhpur Flamenco and Gypsy Festival (JFGF) established in 2014. Photo courtesy of JFGF.

Thus flamenco is not only an artistic genre, but a way of life, which for many outsiders is expressed in the romantic freedom Carmen personifies. For its foreign adherents, a trip to Spain is a necessary pilgrimage to imbibe the ambiente, to enjoy, even if momentarily, a life in which cares are dissipated in music and dance, and emotions can be externalized and extemporized within an aesthetic framework. ${ }^{9}$

In the early twentieth century, flamenco ceased to be only a localized folk genre and became a performance art theatricalized for the stage. It was later appropriated by the Franco dictatorship (1939-1975) to represent all of Spain as a tourist attraction. ${ }^{10} \mathrm{No}$ longer only a spontaneous expression of feeling to be shared with close associates, flamenco now shares with ballet and Indian classical dance a complex structure and rigorous technique requiring several years of training, and thus demands significant commitment and dedication on the part of those pursuing it. However, unlike those classical genres, flamenco allows and expects the dancer to compose his or her own choreography, improvise, and put a strong individual stamp on the movement while at the same time maintaining its defining traditional characteristics.

Flamenco is perhaps unique in incorporating so many diverse sources - Morisco, Jewish, African, New World, Spanish folk as well as being identified with a specific 


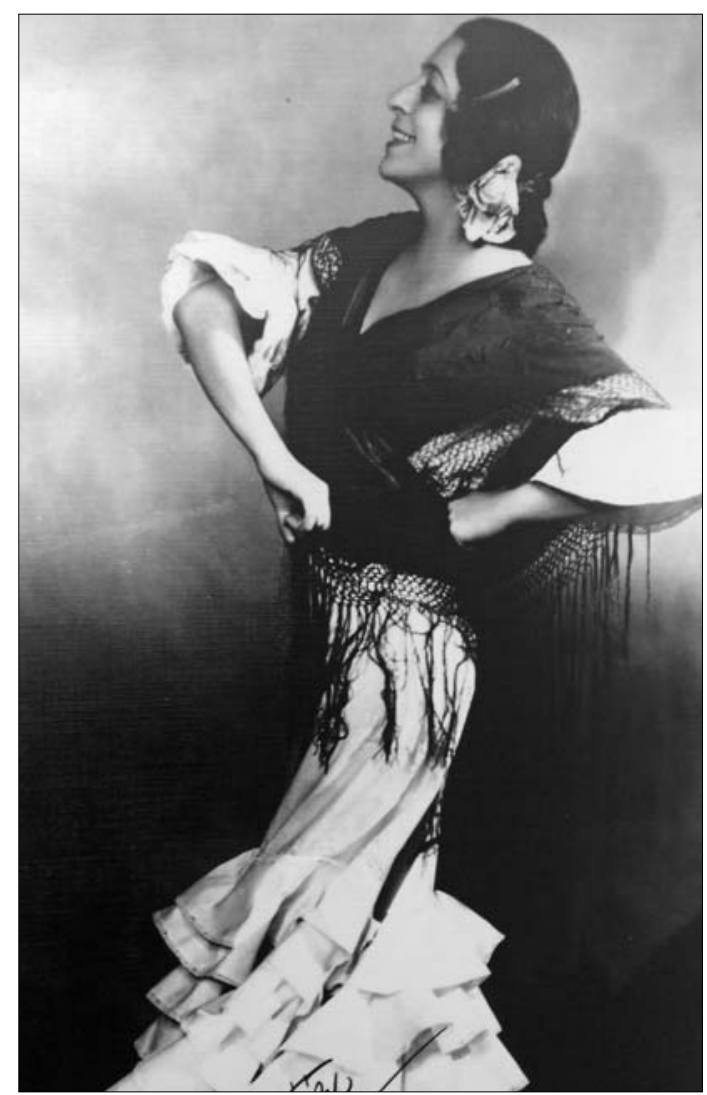

La Argentina (Antonia Mercé, 1890-1936), the first recorded Spanish dancer to perform in Asia, danced in Tokyo in 1929 where the impressionable Kuzuo Ohno saw her and nearly fifty years later created his butoh masterpiece, Admiring La Argentina. Photo courtesy of Museum of Performance and Design.

ethnic minority and maintaining its strong affiliation even as it evolved as a global phenomenon. In the process, however, the dominance of the cante (song) in the pueblos gave way to the ascendancy of the baile (dance) for urban and foreign audiences. By loosening its linguistic ties, freer rein was given to the dancers to absorb new melodies and movements into the structure of its rhythms, or as Yoko Aoyama puts it, the dance's 'particular combination of authenticity and hybridity' ${ }^{11}$

Flamenco's history and development can be imagined as an hourglass - its varied eighteenth- and nineteenth-century sources funnelling through the sensibility and needs of Gitano artists who gave it its characteristic sound and look, and now once again expanding outward as it incorporates external influences from jazz, hiphop, contemporary dance, and avant-garde theatre. Both its clearly defined identity and its cross fertilization assist in its international appeal and adaptability.

\section{Flamenco Comes to Asia: First Encounter}

Flamenco artists began touring internationally at the beginning of the twentieth century. The first Spanish dancer recorded to have performed in Japan was Antonia Mercé 'La Argentina' (1890-1936), who came in 1929 as part of an extended Asian tour. ${ }^{12}$ Trained in ballet, she presented a variety of Spanish dances: folk, flamenco, escuela bolera, as well as excerpts from Manuel de Falla's new composition, 'El Amor Brujo' ('Love, the Magician', 1925).

Seeing her perform at the Imperial Theatre in Tokyo, the young Kazuo Ohno (1906-2010) was entranced, and fifty years later the famed exponent of butoh created his homage to her, Admiring La Argentina (1977), which he continued to perform and develop for the rest of his life. 'Butoh', meaning 'stomping dance' - which refers to its earthbound nature in contrast to the skyward leaps of European ballet - aligned it with the downward force of flamenco, and was perhaps influenced by this exposure. Ohno's son Yoshito recalls:

Watching this piece, I'm never sure whether Kazuo is quietly possessing her spirit, or if La Argentina herself has entered his body. One has the impression that he dances both for and with her. I've had to ask myself on many an occasion if it's not a case of mind over nature. ${ }^{13}$

Flamenco's entry into Japan was thus first embodied androgynously despite La Argentina's clearly gendered performances.

The next encounter occurred in 1959, when Pilar Lopez Júlvez (1912-2008) - the lesser known sister of Encarnación López, 'La Argentinita' (1898-1945) - went to Japan after her sister's death and was seen by Yoko Komatsubara. Smitten at first sight, Komatsubara recalls:

The passion I felt when I first saw flamenco crawled deep inside me. I love its dramatic char- 
acter, the pain, the exhilarating joy, the passion, the suffering. For me, flamenco is life itself. Having been brought up in a family of artists where rehearsals were more important than school, I was encouraged to pursue artistic activities. Because of my family background in Japanese traditional arts ... . I spent my earlier years doing buyo [traditional Japanese dance], and my teenage years studying ballet and theatre. All these disciplines later contributed to my development as a flamenco bailaora [dancer]. ${ }^{14}$

Known now as La Yoko, she went to Spain and was the first to bring flamenco back to Japan. While foreign observers at the time comment on flamenco's fiery passion, rarely do individuals admit to being so moved as to pursue it in such a pre-emptive manner. ${ }^{15}$

Two films assisted her to launch flamenco's popularity into mainstream Japanese society. Los Tarantos (1963), a Gitano Romeo and Juliet, starred Carmen Amaya (19131963), who, born in a barrio of Barcelona not unlike the one depicted in the film, was instrumental in bringing 'Gitano aesthetics' to the international concert stage. ${ }^{16}$ Intense, dynamic, forceful, and androgynous, Amaya's dancing style that has come to dominate current flamenco inspired Shoji Kojima to become Japan's first male flamenco dancer. ${ }^{17}$

The second film had a profounder effect on Japanese women. According to Japanese musicologist Masami Takaba, Carlos Saura's Carmen (1983) exploded the popularity of the dance. ${ }^{18}$ The film adapted the opera as both a flamenco ballet and a backstage contemporary love story. Starring newcomer Laura del Sol in the title role, she acted and danced Carmen with defiant seduction opposite Antonio Gades, who was both her lover and the choreographer of the ballet. A macho dancer and backstage persona, Gades, like Pygmalion, tries to mould her into his idea of Carmen but, in the end, she resists, transgressing all traditional boundaries.

Dutch dancer and scholar Yolanda van Ede writes that another event added to flamenco's attraction - the performance of Cristina Hoyos (who had starred in two Saura films) at the 1992 Barcelona Olympics. ${ }^{19}$ The sight of her dancing solo before thousands in the enormous arena and the millions watching on television, and then being picked up by a rider on horseback and together galloping out of the ring, created a sensation. She embodied Carmen's bravura, artistry, and romantic female individualism. The Spanish dancers who came to Japan to perform in the following decades were, in their own ways, Carmen's avatars and personified the aspirations of the Japanese female dancers.

\section{The Homeland Quest in India}

Unlike the Japanese pioneers, Indian performers evinced little interest in flamenco. Instead, Spanish innovators at the beginning of the twentieth century, curious about their own roots, brought the two together. ${ }^{20}$ Vicente Escudero (1888-1980), a self-taught flamenco dancer, criticized by traditionalists for dancing outside the compás (traditional rhythm patterns), created his own style. In 1912, he moved to Paris and, inspired by avant-garde theatre and cubist painting, brought modernist aesthetics into his choreography. Though not a gypsy himself, he travelled throughout the Middle East in search of flamenco's roots, and believed he found them in the Roma dances of Rajasthan. He became one of the first European dancers to watch Indian dance in situ, not to exploit its exoticism but its familiarity, and to claim its connection to his own flamenco style.

In Paris in 1930, Escudero met Uday Shankar (1900-1977), the Indian dancer who,

Vicente Escudero (18881980), who revolutionized male flamenco dance to become the first 'cubist' flamenco dancer, went to India seeking flamenco's roots. Photo courtesy of Museum of Performance and Design.

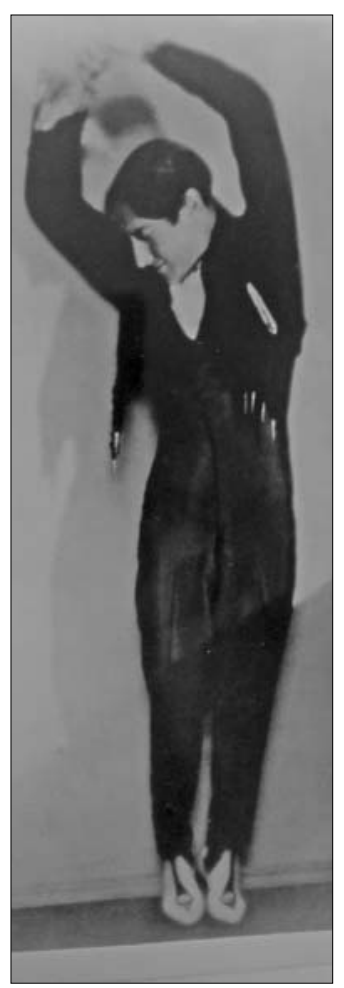


like himself, was a non-traditionalist innovator without formal training, and had become well known for integrating Indian folk dances as well as European theatricalism into his choreographies. Shankar and Escudero both became sensations in New York when they were among those billed in Sol Hurok's Festival of International Dance in 1932, for which the impresario emphasized their differences: 'the delicacy and originality of Shankar, and the fire and fury of Escudero'. ${ }^{21}$

What neither Shankar nor Escudero did, however, was to perform in each other's countries, nor is it known whether they ever collaborated. ${ }^{22}$ One of the earliest direct encounters between kathak and flamenco occurred in 1985 between guru Pandit Birju Maharaj and Gitano innovator Mario Maya. After performing with his troupe of female dancers in Madrid, Maharaj improvised a rapid exchange of rhythmic footwork with Maya, in a 'brief but intense encounter between two dancers standing opposite and gave a memorable demonstration of the points in common between the forms apparently so distant' ${ }^{23}$

Commenting on the experience, Maya stressed that although the Gitanos had been five hundred years in Spain, the subconscious influence of Hindu kathak could be felt. In contrast, Maharaj focused on the similarity of structures in footwork and rhythms rather than a subliminal historical connection. This reveals their differing stances towards each other: for flamenco, kathak offers a link to an ancient prestigious past: for kathak, flamenco offers a gateway to the future, to modernity and to wider international recognition, such as flamenco's universal appeal. ${ }^{24}$ These differing interpretations continue to impact the relationship between Indian and Spanish collaborators.

\section{The Japanese Attraction}

Japanese ethnomusicologists, the dancers themselves, Spanish flamencologists and performers, and even dance scholars from other countries have been intrigued by the Japanese obsession with flamenco. Yuko
Aoyama suggests the Japanese public seems to see flamenco as not a truly 'Western' art, but something that is somehow familiar since it is one of the few European musicdance forms that took advantage of music outside the Christian majority, and incorporated the rich musical mélange of Spain's seven hundred years of Moslem rule: 'To the Japanese audience, flamenco music and dance is neither Western nor Eastern, resulting in what one may call an 'occidental mysticism. $^{25}$

Aoyama avers that the Japanese perceive Spanish culture as perhaps a 'cultural parallel' more than a 'cultural opposite' in that both Japan and Spain are on the fringe of the Western metropole. ${ }^{26}$ Although Japanese flamencos are quick to acknowledge the obvious differences between Spanish and Japanese cultures, the more they acculturate, assimilate, and domesticate flamenco, the more they insist on the deeper affective similarities between the two. ${ }^{27}$

When Japanese students first showed up in the Spanish studios, they were often objects of ridicule because their approach was so methodical and analytical - the antithesis to the Gitano norm in which one learned organically from childhood in a family setting. The bemused teachers would relate how a Japanese student wanted to know the exact degree of the angle that the arm was held - such detail being risible because the dance had never been so dissected and the teacher had no means of answering.

Criticism of the Japanese studiousness, stiffness, and 'lack of spark' occasionally still surfaces, but as many have now won awards in Spanish competitions and/or embraced the relaxed lifestyle in Andalusia, they have been embraced in turn by Andalusians, in part due to their financial support, but also for their undoubted afición, or passion for flamenco.

In addition, derived from their Confucian ethic, the Japanese respect for teachers created strong personal relationships. As a persecuted ethnic minority, the Gitanos have been admired for their artistic talents, but Spanish society had never respected them in the way that the Japanese regard their maes- 
tros, and thereby created a particular bond between them.

Flamenco has at least three areas of appeal for Japanese women: (1) providing a legitimate expression of a full range of personal feeling, including aggression, hostility, ecstatic joy, and deep sorrow not allowed the female dancer without social or aesthetic unease; (2) allowing any age and any body type because it was created from the rapport between the individual and her community; and (3) its ability to express an androgynous way of being.

Although traditional flamenco dance often presents clearly defined gender signifiers through costuming, movement, and carriage, with the women focusing on brazos (arms and upper torso movements), and the men on taconeo (footwork), Carmen Amaya broke the barrier between them by incorporating male stances and footwork with astonishing speed and force. Moreover, by dancing in traje corto (male costume) she opened up the dance for women to combine upper- and lower-body virtuosity. Contemporary flamenco allows a gamut of gender representation for women, from arch-femininity to travesty, transcending gender limitation and providing multidimensional means of self-assertion.

Flamenco offers a female fantasy of the free and independent woman who is also aesthetically beautiful and desirable - the image that Carmen epitomizes. She is an alter ego that allows the Japanese woman to momentarily step outside all social roles and transcend - or pound into the ground - her subservient social position. When she puts on her shoes and skirt, the dancer becomes an exotic superwoman, a role that can be assumed when dancing in a studio even if it has to be shed once the music stops.

\section{'Japamenco'}

Both Spanish and Japanese believe that it is the liberating expression of raw emotion that appeals to the female dancers, noting that while Japanese have strong passions, their culture directs them inward while flamenco validates a range of their externalization as well as bursts of spontaneity. ${ }^{28}$ No tradi- tional Asian dance form allows female performers either such a wide range of emotions or such extreme and individualized expressions of them.

Yet, as Sayoko Yamaguchi notes, it is not merely the display of passion but the play of withholding and controlling emotion that appeals to women who are the most constrained in the social hierarchy:

It's not difficult for them [Japanese women] to understand the torment of concealing emotions. ... Flamenco is actually as much about holding it as letting go. Energy comes from holding it within, and that fits well with the Japanese psyche. $^{29}$

Flamenco offers particularly attractive forms of counterculture among women who are taught to speak and walk softly but, as Yoland van Ede discovered, the Japanese flamenco studios are exceptionally loud with foot stomping. She suggests there is an emphasis in volume over quality in the sound, because flamenco offers

a stage for resisting local Japanese norms concerning proper female behaviour that is not only as invisible but also as inaudible as possible. ... 'Japamenco' . . . can be interpreted as an act of resistance against Japanese patriarchal society, of female cosmopolitanism against male traditionalism. $^{30}$

The stomping does not merely produce loud percussive music, but is a transgressive act against the confines of Japanese femininity. Mayumi Kagita recalls the first time she encountered live flamenco:

Ms Keiko Sato was so skinny but she stomped the floor and made such a big sound. I was surprised by the impact of her dance. I had never seen that way of beating the floor with your feet. ${ }^{31}$

With practice comes the art of making music with the feet, but initially the loud stomping is both psychologically and physically cathartic, helping to relieve the stress and frustration of women in societies with constraining formalities of courtesy and quiet.

Emotion is expressed not just in the speed and force of the feet, but also in the proud bearing of the head and torso. Flamenco exaggerates the uplifted chest and displays 
an arrogant self-absorbed facial expression, clearly counter to Japanese norms of modesty. In most traditional Asian dance, female performers are expected to smile or at least maintain a neutrally pleasant expression when they are dancing for others, but flamencos often wear what K. Meira Goldberg has labelled 'the Gitano mask', an expression of disdain, scorn, or indifference adopted by Gitano dancers when they transitioned from being folk performers in their own communities to being professionals on stage before outsiders; the 'mask' serves as a protective shield which can both contain and distance Gypsy oppression. ${ }^{32}$ The serious introverted facial expression and proud erect posture opened up new modes of expression for the Japanese woman, not only in the range of previously prohibited emotions, but also of individual self-affirmation.

In addition, most dance aesthetic requires the seeming effortlessness of the movement to make it appear 'natural' and any revelation of effort indicates a failing. Flamenco, on the other hand, makes the most of expressing effort as if such vulnerability invites the observer to journey with the artist as she strives to dig deeper into the wellsprings of feeling. The frowning concentration of the dancer, the closed eyes and tight-lipped grimace of the guitarist, or the singer bobbing up from the chair, hands pumping the air: all display the physical and emotional strain to tap into the very source of emotion, the duende, the spirit of the art in the moment.

\section{A Generational Continuum}

One of the great appeals of flamenco is that it accepts any body and any age. What is important is commanding the compás, carrying off the cultural geste behind the movements, musicality - establishing a relationship with the cante, and embodying the duende. But behind all these characteristics is the suffering of a persecuted people, and only those who have it running through them are revered in the flamenco community.

Since flamenco is sung and danced among extended family members, children to grand- parents partake with equal enthusiasm and support. Most of the current flamenco stars do not have balletic physiques, but exploit their individual body types. In addition, though younger dancers break away and appropriate flamenco for their own generation, they remain respectful of their antecedents, creating works dedicated to them.

Gitano flamencos provide their own generational continuum through learning from elders, then taking the dance in new directions, and cultivating the very youngest. La Yoko dancing in her seventies, like her Gitana counterparts, demonstrates there is no limit. Mayumi Kagita describes the effect of flamenco on her students:

Their facial expression becomes richer and they seem to shine - their inborn beauty starts to show. ... Their bodies change too, but that doesn't mean they become skinnier. Flamenco does not suit skinny dancers like those who do ballet. Toughness, strength, and feminine bodies are required. As people practise flamenco, their muscles change and their strength gradually begins to appear from the centre of their bodies. ... No set standard, flamenco allows for a variety of body types. $^{33}$

The costuming, too, appeals because the long dresses based on the style of the nineteenthcentury modistas (dressmakers) are unabashedly colourful and accessorized with equally flamboyant jewellery and combs that are attractive antidotes to the world of bland, uniform and anonymous office attire. In addition, the cut of the dress both covers the body and yet outlines and reveals it, according to the wearer's taste and discretion. Flamenco costuming is an ever-changing fashion that is dependent on many factors, and impacts alterations in the dance as well. ${ }^{34}$

Although Carmen has been belittled to represent cheap sensuality, Merimée's character dies for freedom, not love. The early romantic European visitors to Spain might have imagined flamenco eroticism was directed to the observer, but female dancers Gitana and paya (non-gypsy) - have fought a long battle to take control of the meaning of their dance, to separate it from the stigma of prostitution during the Franco era, achieve 


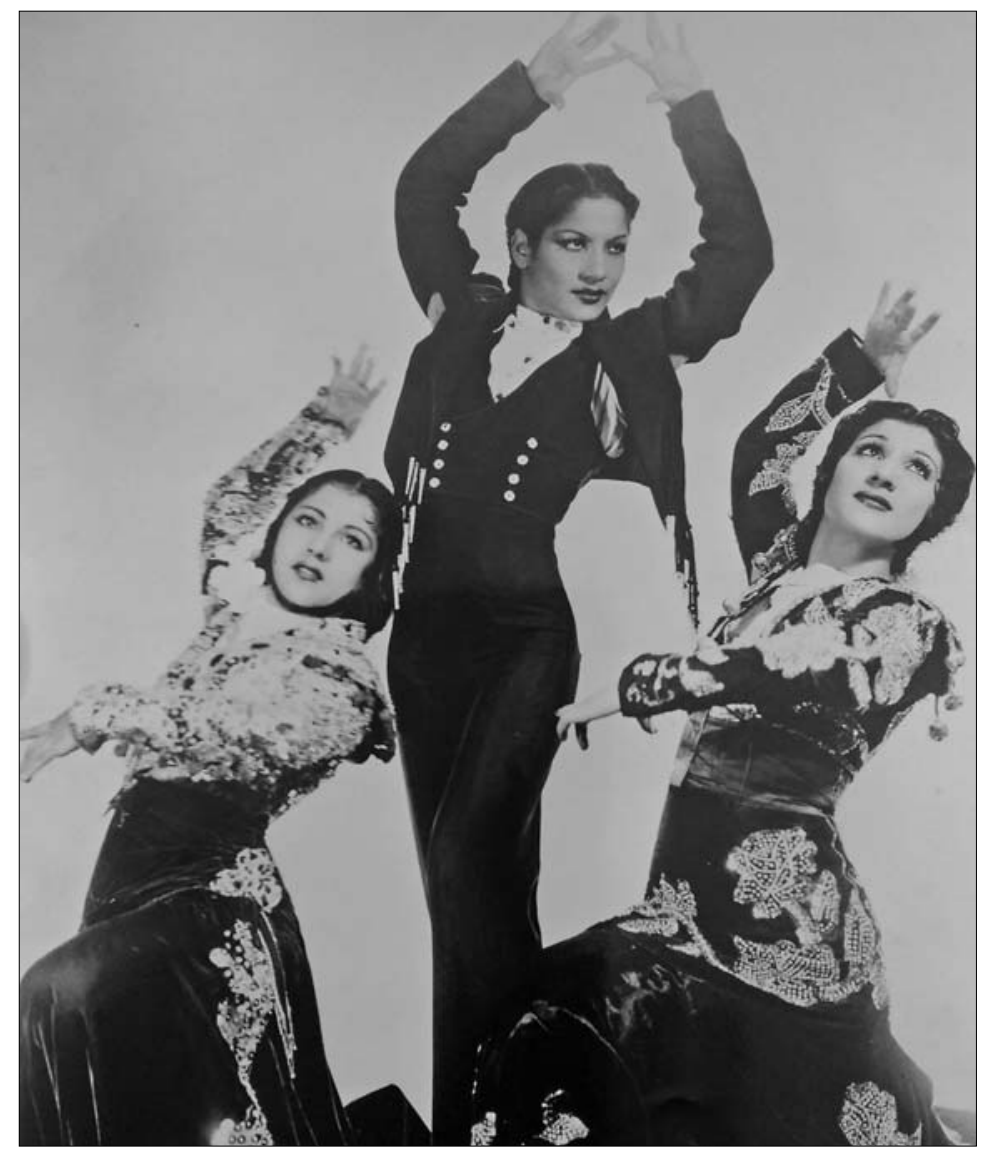

Carmen Amaya (1913-1963) made it a signature of her early performances to dress in the male costume traje corto to highlight her command of masculine posture and extraordinarily fast footwork, opening the door of androgynous dance for other female performers. Photo Courtesy of Museum of

Performance and Design.

technical parity with male performers, and make their performance expressive of the full range of their human experience.

Androgyny is not what is usually associated with flamenco - in the mid-twentieth century it was almost a parody of rigid heterosexual stereotypes - but the 'gypsy aesthetic' introduced by Carmen Amaya to the international stage created a platform for androgynous expression.

Even within strict gender differentiation, El Vito, the nineteenth-century dance of the female bullfighter, was performed by nonGitana women in trousers. ${ }^{35}$ Amaya was the first Gitana to perform regularly in traje corto and adopted much of the masculine style to display her exceptionally fast and strong tacaneo and also play with the gaze, alternating between "the lifted gaze of the "feminine" and lowered provocative gaze of the "bullfighter"' 36

At $4^{\prime} 10^{\prime}$ and 90 pounds, Amaya had a lithe boyish figure; her arms were unusually mus- cular for a woman, and some photos show her with a square jaw that is uncannily androgynous. This is not referring only to the androgyny of physiology, or cross-dressing and its accompanying mannerisms, but from the dancer's perspective of a sexual neutrality of the spirit, especially as an escape from the burdens of femininity. As flamenco provides a range of emotions, it also allows for a play of gender expression from within the persona of the dancer.

\section{Projecting an Androgynous Spirit}

The androgynous young male epitomized a transcendent beauty in the classical Western tradition, and, in traditional Asian theatre, central male characters such as Rama, Panji, or Yoshitsune, could exhibit a delicacy that might suggest effete over-civilized refinement, but did not impinge upon their warrior status or kingly attributes. Current pan-Asian pop culture idolizes the 'soft masculinity', of 
the bishonen (the beautiful youth), who are nonetheless proficient in the martial arts. ${ }^{37}$ Female performers have a more difficult time accessing and projecting the balance that makes androgyny attractive. Contemporary ballet has done so by insisting on a body so thin it retains its child-like quality because the adult female body was too burdened with sexual signification. The dancer who wants to be free from it first has to de-sex herself before so that she can reinscribe a 'seductive ambiguity'.

Emilyn Claid defines this androgynous quality as not a transcendental union of masculine and feminine that excludes difference, nor a feminist negation, nor the creation of an abstract empty body, but one fully charged with vitality:

The body temporarily spans between identities that emerge in the gaps between things ... hybrid bodies. ... I am refiguring androgyny as an embodied play between gender characteristics, spanning across, knowing the extremes - playing the many combinations in between - in one body. ${ }^{38}$

Amaya moved laterally across genders, as if, along with the rhythm, she dominated which profile she was going to accentuate. She took freely from the traditions of both sexes; 'She mixed feminine sensuality, vulnerability, and expressivity with the male idea of risk. ${ }^{39} \mathrm{Her}$ androgyny emerged not only from the furious exhibition of her speed and strength, but also from her refusal to be coy. Amaya's straight unflinching gaze was provocative because it was such an intense expression of concentration - her face was the extension of her body, not something separate or added to please or appease the audience.

American critics did not know how to respond to this direct challenge, but moved by Amaya's power, expressed their ambivalence by crediting it to her primitive race:

The notion of Gitanos acting out the sensual and physical freedom which other cultures only dream about is only acceptable when they as a people are viewed as 'exotic', or even non-human, existing in a different plane of movement and sound as well as of social behaviour. 'They danced like creatures ... full of the divine fire. ${ }^{40}$
The reviews characterized her as 'sensational, perhaps attractive, but not quite human, and certainly not an artist. She lacks distinction and is Gypsy, associated with primitivism.... She is passionate but not sexy. ${ }^{41}$ Precisely. Amaya's passion was not directed towards the male observer, but towards herself in relation to her dancing body. Unable to concede this possibility, American critics compared her directly to a force of nature, the 'Human Vesuvius'. ${ }^{42}$

Amaya set the standard that continues today, both the ascendance of Gitano aesthetics over Spanish classical dance practised by her predecessors and as a model of female androgyny for a woman who was spirited, forceful, playful ... and beautiful. As a dance that allowed for personal expression, intensity, and passion but was not constrained by conservative notions of female propriety or sexual allure, flamenco created a liberating space for both Gitanas and Japanese women oppressed within their own societies.

Flamenco inversely corresponds to Japan's own cult of female androgyny in the century-old Takarazuka Revue, the Japanese sentimental theatre in which the otokoyaku, the women playing the male leads, are the most popular. They are attractive physically, but 'the goal is not to trick the audience into believing that the otokoyaku are men, but to present an idealized male character through a woman's body'. ${ }^{43}$

The otokoyaku present the androgynous exterior, but I suggest that flamenco allows women to project an androgynous interior spirit. ${ }^{44}$ Ian Buruma cites the critic Fumiko Imaizumi, who

believes that the evident desire not to be female is often misunderstood as a kind of worship of men. Girls do not want to be men, but their deepest desire is to be neither male nor female - in short, they wish to be sexless. This is not because of some innate fear of the female condition, some biological taboo, but because they realize that becoming an adult woman means playing a subservient role in life. ${ }^{45}$

Flamenco provides the opportunity for the dancer to disengage her own sexuality from prescribed gender roles and explore it from a position of strength. 


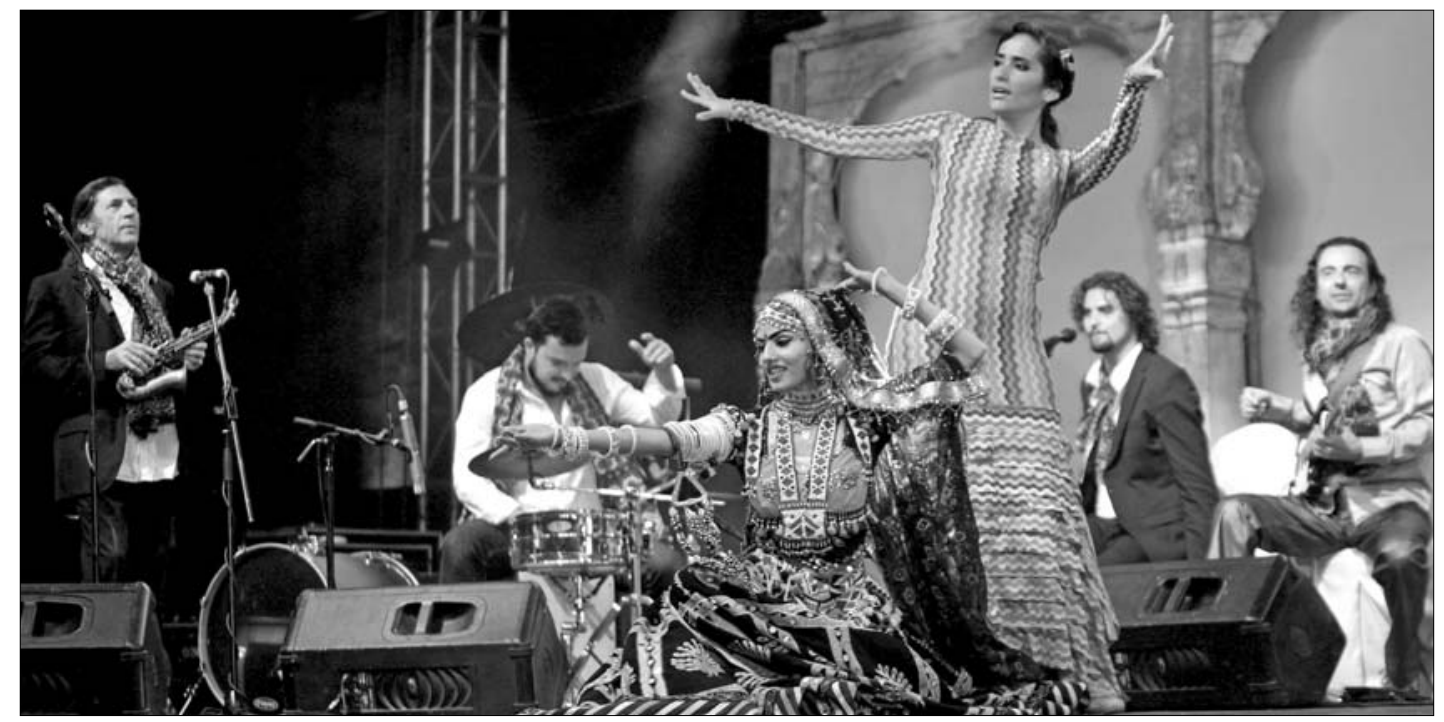

Flamenco and Kalbeliya performers improvise together at the Jodhpur Flamenco and Gypsy Festival. Photo courtesy of JFGF.

Also relevant in the Japanese lexicon is the concept of akogare - usually translated as 'yearning', 'longing', or 'adoration'. Used to describe the feeling for people, places, and ideals that seem impossibly far away, it is an idealization of the unattainable. The fictional Carmen is certainly unattainable - except when one is dancing and can imagine oneself as her.

There is also a streak of deep pessimism running through akogare, a tragic sense of mono no aware, the pathos of things. ${ }^{46}$ When Japanese describe their affinity for flamenco, they claim to share this great sorrow culturally, the aesthetic of the beautiful sadness. Japanese embrace flamenco cante jondo's tragic view of life even in the bursts of ecstasy and fun. More than merely a cathartic release of emotion, flamenco dignifies the struggle, aware of the tragedy of existence even while not forgoing self-irony. Dependent on a guitarist, singer, and palmera (hand-clapping accompanist), the dancer is nonetheless a soloist, dancing inside herself and for herself, a luxury for women who feel near the bottom of a hierarchal society. The Carmen that resides in their imagination will remain both an unattainable dream, and a vitalizing spirit that inhabits their bodies each time they stand before the studio mirror and begin to dance.
There is no Carmen epitomizing either the kathak or Kalbeliya dancer, nor has there been any indication that either Merimée's or Saura's Carmen has held any particular fascination for Indian women, although her stereotype as 'erotic exotic' is penetrating popular culture via Bollywood dance. ${ }^{47}$ Instead, she is sublimated in a pursuit of a 'pan-gypsy' culture. In 2009, Ion de la Riva, Spain's ambassador to India, grandly proclaimed 'Flamenco is believed to have originated in India' to initiate the Spanish government's collaboration with the Rajashan International Folk Festival (Riff), which established the first Jodhpur Flamenco and Gypsy Festival.

\section{India: Kathak and Kalbeliya 'Connection'}

While individual dancers continue to be motivated to explore the dance liaisons between various forms of Indian dance and flamenco, cultural managers both in Spain and India, especially Rajasthan, have ulterior motives for emphasizing the ostensible links between them. The Gitanos, rather than delving into the multifarious hybridity of influences exerted upon their music and dance within Spain, such as Arabic and Sephardic music, seek instead their own ancient lineage to a Roma homeland. 
The Indian contingent is keen to raise the status of the local Roma dance and at the same time promote kathak as the origin of a renowned Western dance - reversing the flow of colonial and global impact from East to West.

\section{Roma Heritage}

Chaman Lal's Gipsies: Forgotten Children of India (1962) claims that the Roma originated in India; this is primarily based on linguistic evidence and Firdausi's Persian epic Shanameh (1011) which describes the arrival and departure of 10,000 musicians from India, and labels them 'Luri'. Whether or not these 'Luri' have any relation to Roma remains in doubt. ${ }^{48}$ Moreover, the Roma migrations across Europe via Persia took place long before anything resembling the modern flamenco, kathak, or Kalbeliya dance took shape. After investigating the rhythmic and kinetic similarities between kathak and flamenco, Miriam Phillips, a practitioner of both, suggests that gaps of reliable historical information disallow any certain confluence between them. She also notes the difficulty of ascertaining kathak's relationship to any tribal ethnicities such as the Kalbeliya:

It is true that the Roma came from northwest India and migrated westward in multiple waves, with many settling in Spain. It is also true that Gitanos [sic] played a critical role in the development and perpetuation of flamenco. What is unclear is how those peoples, now identified in India as 'Roms', may have influenced kathak. ... . Therefore, which Rajasthan tribal people influenced the development of kathak - true Roma or not? And if Roma, what exactly did they bring? What were these people's relationships to the caste of kathakas, if any? One would be hard pressed to answer these questions accurately. ${ }^{49}$

Phillips raises the pertinent issue of the dubious connection between present-day kathak dance and its own supposed roots in the kathakars, a caste of storytellers, but there is no conclusive connection between the two. ${ }^{50}$ She also shows that the similarities between flamenco and kathak, such as their rhythmic footwork, developed long after the Roma left India, making it impossible for any direct Indian involvement in the formation of flamenco. ${ }^{51}$

Thus it is difficult to understand how Gitano performers claim kindred relations with both current Kalbeliya and kathak performers whose relationship with each other is contested. It is more likely that they encountered similar influences in Mughal India and Islamic Spain:

Muslim culture, through the Indian Mughals (1526-1857 CE) and the Spanish Moors (711-1492 $\mathrm{CE})$, had a great deal to do with the development of both kathak and flamenco. However, the hypothesis that cultural and movement influences related to the Muslim Expansion could have been responsible for the bridge between kathak and flamenco is rarely considered. . . Both the Mughal and the Moors descended from Caliphate lineages that had a unique proclivity for the performing arts in their lavish courts. Furthermore, there are acknowledged Indian influences on many forms of Muslim art and poetry, and many Persian-Muslim interfaces in the history and arts of North India. ${ }^{52}$

Negotiating between Hindu religious practice, Muslim court entertainment, and colonial opprobrium, kathak's evolution is a fascinating amalgam of influences. However,

What is now known as kathak did not emerge until the early twentieth century when male and female, Muslim and Hindu, court and rural repertoires were juxtaposed then fused as the classical dance called kathak took its place on the proscenium stage and in the emergent dance schools. ${ }^{53}$

\section{Disappearing Components}

Contemporary kathak is structured in sections that separate technical virtuosity, nritta, the pure and abstract dance, from nritya, the mimetic narrative sequences of abhinaya which stimulates aesthetic emotion in the observer through a combination of rasa or sentiment with bhava or mood presented in codified movements and gestures.

Nritya, because it enacts cultural texts, rarely appears in collaborations with flamenco. Flamenco and nritta allow for two virtuoso dancers to improvise and respond to each other, but kathak separates what 


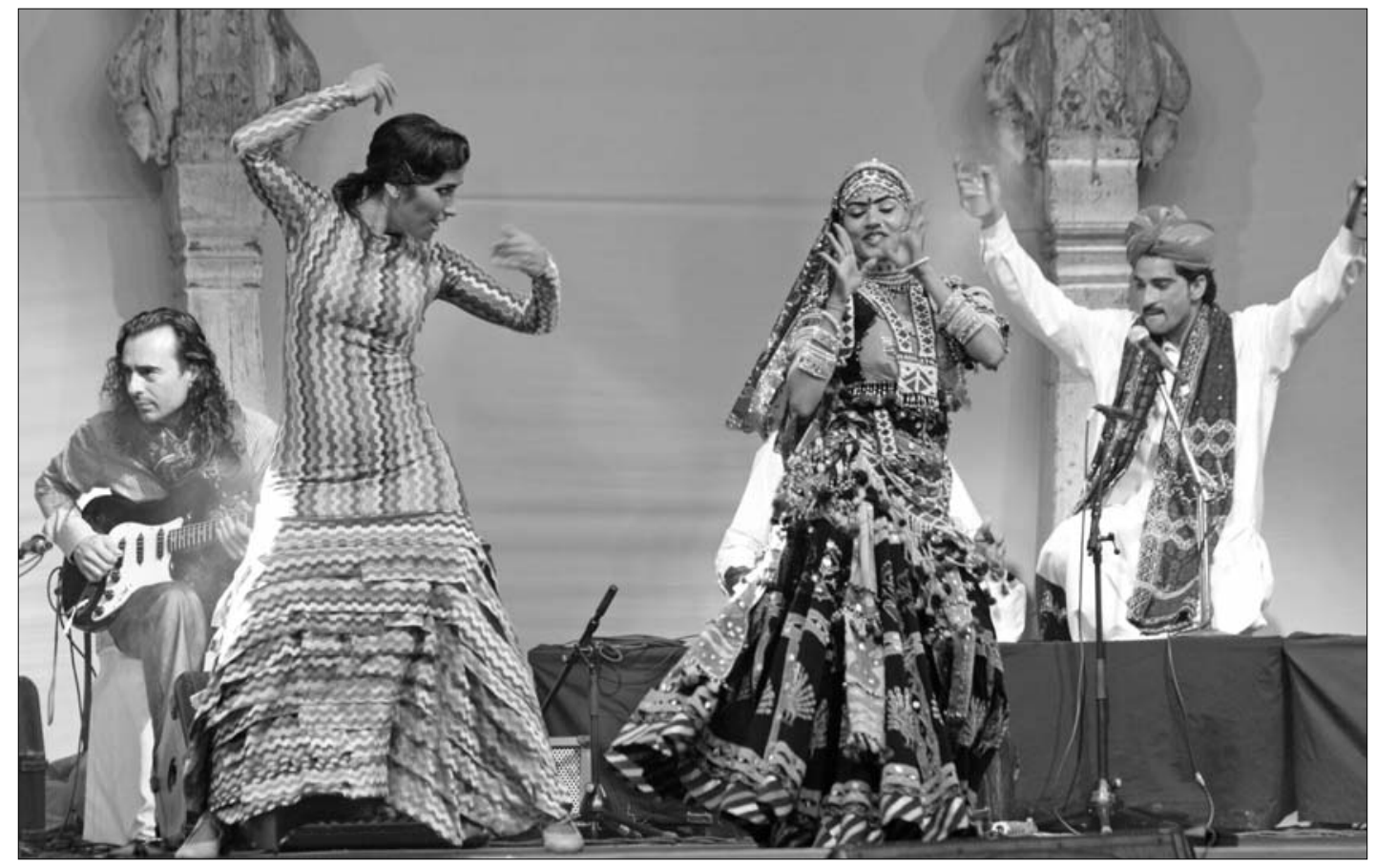

Flamenco and Kalbeliya performers improvise to show the common features of their music and dance at the Jodhpur Flamenco and Gypsy Festival. Photo courtesy of JFGF.

flamenco intertwines: the body's physical movement and emotional expressivity. The dancer embodies the cante's mood and the palo's rhythmic accents in order to convey her own individual feeling.

Kathak, by contrast, involves rasa aesthetics to evoke a specific emotion in the audience that is produced by means of precise gesture and facial expression. Flamenco also has culturally-indicative emotional modes, but no codification of their expression. Its cante, originally the most important feature in flamenco, rarely tells a narrative, but evokes culturally specific expressions of yearning, humour, and lament.

Since originally the song and movement were to express what the performer was feeling at the moment, the concept of preparing a set piece for the professional stage was counter to the whole raison d'être of flamenco. But having become professionals, flamencos now know how to act to motivate their dance. Moreover, outside Spain most audiences do not comprehend the words of Andalusian cante, and thus by the reduction or absence of these two word-oriented components - nritya and cante - the collaborative representations of kathak and flamenco are culturally incomplete.

\section{The Creation of Kalbeliya}

Further inquiry into the 'antiquity' of Indian Roma dances also reveals that the version singled out for national promotion - the Kalbeliya female dance (which, like flamenCO, was recognized by UNESCO in 2010) - is a recently fabricated amalgam. Ayla Joncheere, who trained as a Kalbeliya dancer, uncovers the various Indian players who concocted a dance that was unknown by the Kalbeliya before the $1980{ }^{54}$ She writes that, although Kalbeliya women sang for money, they did not dance publicly. ${ }^{55}$

Gulabi Sapera, credited with formulating the style, was recognized by Rajiv Gandhi and encouraged to teach it to other women. It evolved 'into up-tempo adaptations to preexisting local Rajasthani dance forms' and includes acrobatic contortions and snake-like movements because of the reputed connection with snake-charmers. ${ }^{56}$ Marking the 
rhythm through torso and hip rather than feet makes the dance more like belly dance than either flamenco or kathak, despite the heavily ornamented costume, which completely covers the body.

Appearing alongside flamenco dancers at the Jodhpur Festival, the Kalbeliya dancers primarily engage in constant whirling turns. Joncheere writes that, while the singing has more viable cultural roots of communal expression,

Kalbeliya dance is artificially portrayed as a traditional art form based on the everyday life practices of the community, although in fact it is a performing art that was consciously designed for external spectators. ${ }^{57}$

It emerged in response to outside stimulus and as a means of economically improving the lives of dancers' families.

Despite the historical infeasibility of mutual influence, cultural ministers press ahead to promote collaborations, with both the Spanish and Indian press glibly repeating that 'India is the homeland of flamenco'. While the pairing of flamenco with kathak or Kalbeliya dance continues to fascinate general audiences and poses intriguing challenges to choreographers grappling with how to highlight both the unique identity of each and at the same time bring out their commonalities, to a close observer cognizant of the traditions involved, it is the dissimilarities that become apparent in most sideby-side displays because both lose their particularized evocation of emotion:

While there are numerous differences in the foot's relationship to the floor, the carriage of the arms, it is in the facial expression that evident cultural differences exist. ... Kathak facial gestures are somewhat codified, whereas flamenco expression is more individualized. ${ }^{58}$

These differences are pronounced because they refer to the differing origins of the dance - pleasing gods and kings or protesting against personal sorrow and communal suffering.

Dancers from both the kathak and flamenco traditions initiate collaborations, while the Kalbeliya involvement is primarily arranged by third parties such as the Jodhpur festival. Flamenco has also been combined with other Indian dances, such as bharatanatyam and odissi with which no historical connections can be claimed. Many of these choreographies initially take place in the cosmopolitan dance centres of New York, London, or Paris, where practitioners are in contact with numerous forms of dance and theatre and whose environments are as conducive to experiment as they were for Escudero and Shankar in their day.

\section{To Fuse or Not to Fuse}

Some dancers have striven for fusion, building upon the premise of their similarities, such as 'Flamenco-Natyam', created by New York-based bharatanatyam exponent Rajika Puri, and Egyptian-American flamenco La Conja, which toured India in 1998. The Indian Council for Cultural Relations (ICCR) sponsored the filming of a fusion performance in Delhi by flamenco Omayra Amaya and kathak Shovana Narayan in 2003, where both dancers said that they wanted to 'push' their art forms in new directions through fusion, citing the common practice of Bollywood dance to incorporate other dance styles. ${ }^{59}$ However, offering the synthetic bowdlerized Bollywood as an example to follow undermines the complexity and sophistication of the two older forms.

Bharatanatyam dancer Sohini Roychowdhury resides in Madrid but not because she was inspired by flamenco, which she uses to build up interest in Indian dance. She claims to have 'learned' flamenco, but only to get a taste of it. Dancing her version of it in India, she reveals condescension towards its inferior status:

Opinion-makers might raise their eyebrows since they might find it difficult to accept how a tribal dance form [flamenco] can be merged with the Tanjore form of bharatanatyam that is over 2,500 years old. ${ }^{60}$

Since events like the Jodhpur festival are making connections (and equivalences) between Indian Roma and Gitano performance, 
both share the inferior 'tribal' status in the Indian cultural hierarchy that privileges the classical dance.

Within Spain, however, Gitano performers take the opposite view - their art is the more evolved development of the ancient Indian forms. Romali (2008), produced by flamenco diva Manuela Carrasco, included a kathak dance by Maha Akhtar, granddaughter of Spanish dancer Anita Delgado who married an Indian raja. Aktar danced a few basic kathak sequences and made a few flamenco poses but she was clearly not in the same league as Carrasco. Both dancers averred that they were not doing fusion, and Carrasco insisted that 'she wanted to dive into the origins of flamenco to propose that the future is not in their fusion, but in stepping in the footprints left by the elders to project them'. ${ }^{61}$

Her presentation was an homage to the flamenco lineage, and she idealistically sought more than technical experimentation, voicing the yearning of a marginalized people to find kindred in the Indian Roma, saying it was an 'invocation for the concord, tolerance, and equality through the understanding of the Hindu art and its relation to Andalusian culture. ${ }^{62}$ However, the Roma connection was absent as Akhtar is not gypsy.

\section{Kathamenco}

Others engaged in collaborations are equally adamant that they are not making fusions, but experiments in 'transcultural hybridity', especially among dancers/choreographers in the Indian diaspora. Anurekha Ghosh, a kathak dancer based in the UK, has incorporated flamenco into her 'nouveau kathak' calling her creations 'juxtaposition' or 'dialogue' to create a new dance language. Also adopting the term 'kathamenco', she says:

My Kathak is different in a way.... I dance with a lot more energy.... This approach comes from the West, from contemporary dance. ... When I went many times to Spain, I stayed close to Flamenco dancers and have many Spanish students. Then I have also taken some influences from Flamenco. ${ }^{63}$
Her visits to Spain resulted in Humsafar (Companion, 2006), in which she integrated flamenco into her kathak as well as grounding both traditions within contemporary dance. The dancers were all kathak trained, and performed barefoot but without the ghungroo bells worn around the dancer's ankles. They swish their skirts, pirouette, clap, and slap their thighs and rotate their wrists like flamencos while their feet keep time with the Hindustani music. That the movement was visibly extracted from both traditions, often skilfully combined, suggested fusion more than juxtaposition.

Juxtaposition was clearly apparent when Ghosh worked with Spanish dancers in Bonded Passion (2003), and included the de rigueur 'conversation' of back-and-forth repetition of rhythmic footwork between them. Ghosh notes that what she has incorporated more successfully is more muscular movement and an energetic extroverted expression; her gaze is not modest but assertive, and not smiling but alive. She and her dancers also allow more individualized expression to play across their features, which perhaps has as much to do with living in the UK as adapting flamenco.

There are many examples of Indian collaborations with flamenco, but two strands tend to emerge from the encounters: solo Indian dance incorporating some of flamenco's idiosyncratic gestures and 'fierceness' into her tradition, and the give-and-take between a solo Indian and flamenco dancers sharing the stage together. In the latter 'crosscultural jugalbandi', the most aesthetically unsatisfying moments usually occur in transition sections when the dancers attempt modified versions of each other's movements. The distinct cultural nuances of both traditions get lost, replaced by a boring simulacrum of their vocabularies.

The desire to 'blend' results is blandness, the weakness of the fusion emphasizing the incompatibility at the core of each form. The dancers undulate their arms, adopt precious poses, and encircle each other's waists, perpetuating an inauthentic Orientalist pastiche that resembles the early twentieth-century exotic dancers in Hollywood films. These 
exchanges are an intellectual challenge - they cannot take the dancers deeply into their respective traditions. Solo kathak and flamenco evoke different sensations both in the dancer and spectator, and, if made evident in collaboration, pull in opposite directions.

The use of the gaze, in tandem with the arms' relationship to the torso, appears quite opposite. In kathak, the focus is often outward, while the arms close and conceal the body. It is as if the dancer were peering out from behind a veil. In flamenco, the arms generally open and reveal the body, while the gaze tends inward. The focus is often introverted as if looking back into one's life, or it is remote as if looking to distant memory. The expression in kathak tends to be subtle, refined, and transcendental. . . . The expression in flamenco appears more raw, earthy, and emotionally 'out there'. . . . Kathak's expression seems more impersonal, as if the dancer is dancing 'an other' (in the storytelling repertoire, the dancer is in fact enacting a character), whereas in flamenco, the expression appears highly personal - the dancer dances his or her own life. ${ }^{6}$

Since the eyes are key to what the dancer is experiencing and wishing to convey, their distinctly different use suggests significant aesthetic and cultural dissimilarity - difficult to overcome without being compromised.

\section{Carmen Meets Radha}

Katarzyna Skiba writes that current kathak is innovating with ballet, contemporary dance, and flamenco, as well as altering its classical movement vocabulary to be more relevant to modern life. It is liberating the body from the limitations of a particular dance technique:

A specific feature of recent innovative trends in Kathak seems to be the tendency to express personal experiences, emotions, ideas, and opinions, 'a search for one's own Tongue'. The individualized, somatic expression of contemporary performers, exposed to multiple body languages, contributes to the hybridity of aesthetics. 65

So where contemporary kathak dancers extend the boundaries of their dance to allow them more personal expression, flamenco is just one of the contributors to the process.

There is no persona in the kathak repertoire like Carmen who offers a fantasy alter ego to empower the dancer's female role on the stage. Traditionally, in the narrative nritya sequences, the kathak dancer portrays Radha, Krishna's lover, evoking sringara, the rasa of erotic love. This characterization limits her, despite being interpreted as a metaphor for a devotee's yearning for God. Radha does not have an identity independent of Krishna, for she is the one who 'completes' him in kathak storytelling.

Aside from modifying the costume, adapting foreign and other Indian classical forms, and creating dance-dramas that address contemporary social problems, dancers express their emotions more directly by circumventing or eliminating this restrictive female representation in the narratives. Bharatanatyam dancer Chandralekha (1928-2006) broke ground by engaging the interplay of male and female energies, a political understanding through the body and moved away from the use of abhinaya to show that rasa could be evoked at more abstract levels from nonnarrative movement. ${ }^{66}$ These changes internally move the Indian contemporary dance closer to flamenco's range of expressivity, still evoking rasa, but in an abstract and flexible way.

Purima Shah writes how the male kathaks 'transcend gender' in their impersonations of female characters such as Radha, which extends their aesthetic and spiritual exploration. ${ }^{67}$ She does not venture to say how female kathak dancers align themselves when impersonating male characters, as in Sushmita Banerjee's use of an unfamiliar scene in the Ramayana in which Ravana dresses in preparation for Sita, the reverse of the commonplace scenario of Radha dressing for Krishna. ${ }^{68}$ For flamenco women, appropriating masculine free play with unfettered bodies is about extending personal liberty beyond the bounds of female propriety and claiming real gender parity rather than reversing gender roles. Flamenco offered women what classical forms did not - the experience and expression of all 'betweens' in the gender spectrum.

But perhaps the poet and playwright Rabindranath Tagore (1861-1941) was first to note the process by which the female Indian 
dancer had to proceed in negotiating with tradition; how she had to erase and then reinscribe her roles in order to make them capable of expressing the full scope of a woman's imaginative life. He reappraised Indian dance's gender delineations when he observed dancers in Indonesia:

In the case of these two girls, their body transcended its flesh and gave expression to pure bodiless dance, as the poem transcends its words and gives expression to the inexpressible. ${ }^{69}$

His praise for the 'bodiless dance' anticipates his move towards lateralizing gender for the heroines in his dance dramas. Rather than merely a puritanical purge of the sexualized body of the tawaif, the courtesan dancers in the Mughal courts, a 'bodiless dance' is an androgynous transition, liberating the preconceived self from the pre-objectified body.

\section{Indigenous Indian Flamenco}

Despite Carlos Saura's 2014 venture into live intercultural performance with Flamenco India, which toured both Spain and India, it did not have the same impact as his earlier films. As of 2017, Indian women have not taken up flamenco with serious aspirations for professional level performance. ${ }^{70}$ Two have emerged as flamenco performers - not from classical Indian dance, but Western folk and ballet backgrounds - to open studios in Mumbai: Behnaz Khusrokhan Bhandare's Ole! Flamenco, and Shehzeen Cassum's Namaste Flamenco Academy.

Kunal Om, a male Bollywood dancer, was seized by a sudden passion similar to that of La Yoko after seeing kathak dancer Chitresh Das perform with flamenco Antonio Hidalgo Paz in Yatra: Journey from India to Spain (2012): 'I was so enthralled by the performance that I met Antonio after the concert and set an appointment to learn more from him. ${ }^{.71} \mathrm{Om}$ first worked at the Jodhpur Flamenco and Gypsy Festival in 2014 and then went to Granada to study flamenco as well as give Bollywood dance workshops. His video clips show him wearing flamenco boots but dancing to Bollywood music. His movements suggest that flamenco had been appliquéd rather than integrated in his Bollywood style. He has also engaged with kathak dancer Aditi Bhagwat in Flamenco-Kathaa (2017), each displaying their footwork rather monotonously because there was no cultural interaction or individualized emotional expression.

\section{Carmen's Avatars and Nemeses}

In Spain, some contemporary female dancer / choreographers have recuperated Carmen's image as a modern woman, as in María Pagés' Yo, Carmen! (2016). Others have repudiated her (and her cheesy incarnations), in the emergence of the 'anti-guapas' (against beauty) aesthetic. They have shuffled off the outmoded Carmen cliché and exploded previous gender limitations from costuming to movement to explore their own bodies, lives, and emotions.

Belén Maya says, 'We have to renounce beauty. . . . There are many other things to think, feel, create. ${ }^{72}$ She along with Rocío Molina, Pastora Galvan, and Rafaela Carrasco are taking flamenco into new theatrical territory, not merely liberating the dancer from the dance, but embarking on the representation of ideas. Having grown up with flamenco since childhood, they all seek to expand it in order to incorporate more of their imaginative lives and to mount the global stage as contemporary creative artists and not as exponents of a calcified ethnic form. Thus it is easier for kathak and flamenco innovators to meet within the purview of contemporary dance. However, it is in their pursuit of freedom to escape the bonds of femininity that they most resemble Carmen.

But when the bonds have been broken and the boundaries transgressed, what is to distinguish them from other contemporary feminist dancers? And what can their edgy contemporary works offer the beleaguered office worker in Tokyo, when she dreams of something seductively beautiful, intoxicatingly exotic, romantically wild and free? The Spanish flamencas may have shed nineteenthcentury Carmen, but in a distant Asian country she is still the unattainable, the forever 'yearned for' Other. 


\section{Notes and References}

1. Mérimée's lesser known Carmen is far more beguiling and complex than Bizet's.

2. Flamenco was designated as a Masterpiece of the Oral and Intangible Heritage of Humanity by UNESCO in 2010.

3. Yolanda van Ede, 'Japanized Flamenco: Sensory Shifts in a Transcultural Relocation of a Dance Genre', June 2014, p.3 <www.researchgate.net/publication/ 263474507>.

4. Luis Palma et al., 'Flamenco as a Cultural Good: a Dynamic Analysis of the Supply of Live Flamenco Shows in the City of Seville' (Spain), 2006-2013', p. 12 <https: / / editorialexpress.com/ cgibin/conference/down load.cgi?db_name $=$ ACEI2014\&paper_id $=189>$.

5. María Elena Sánchez Ortega, 'Evolucion y Contexto Historico de los Gitanos espanoles', in Entre la Marginacion y el Racismo: Reflexiones Sobre la Vida de los Gitanos, ed. Teresa San Roman (Madrid: Alianza Editorial SA, 1986), p. 13-6o.

6. The term was coined by Ayla Joncheere, Kalbeliya dancer and researcher.

7. The Indian Council for Cultural Relations (ICCR) sponsored the film Rhythmic Echoes and Reflections (2003) that claims 'to explore the universality of various dance forms such as Kathak, Flamenco, American Tap Dance, European Ballet, and Australian Ballet', but instead positions India's centrality as a root of all these dance genres <www.youtube.com/watch?v=1axj3 $\mathrm{RT}_{5 \mathrm{j}} \mathrm{P} 8>$.

8. Miriam Phillips, 'Becoming the Floor/Breaking the Floor: Experiencing the Kathak-Flamenco Connection', Ethnomusicology, LVII, No. 3 (Fall 2013), p. 396-427.

9. Yuko Aoyama claims: 'Flamenco tourism is a unique form of tourism that includes active participation by international tourists - a performative experiment on a transnational scale - practised and consumed through an authentic staging in Andalusia.' See 'Artists, Tourists, and the State: Cultural Tourism and the Flamenco Industry in Andalusia, Spain', International Journal of Urban and Regional Research, XXXIII, No.1 (March 2009), p. 80-104.

10. Michelle Heffner Hayes, Flamenco: Conflicting Histories of the Dance (Jefferson, NC: MacFarland, 2009), p. 23.

11. Yuko Aoyama, 'Cultural Survival as a Geographic Paradox: the Case of Flamenco', in Global Movements: Dance, Place, and Hybridity, ed. Olaf Kuhlke and Adam M. Pine, (Lanham MD: Lexington, 2015), p. $1-21$.

12. Ninotchka Devorah Bennahum, Antonia Mercé, 'La Argentina': Flamenco and the Spanish Avant-Garde (Middletown, CT: Wesleyan University Press, 2000), p. 191.

13. Kazuo Ohno and Yoshito Ohno, Kazuo Ohno's World: from Without and Within, trans. John Barrett (Middletown CT: Wesleyan University Press, 2004), p. 166.

14. Irene Carolina Herrera, 'Yoko Komatsubara: Goya Brought to Life in Flamenco', The Japan Times, 2 March $2005<w w . j a p a n t i m e s . c o . j p / c u l t u r e / 2005 / 03 / 02 /$ stage/goya-brought-to-life-in-flamenco/\#.WlFo-gR97-Y>.

15. Similar claims for the attractions of 'passion' were made for tango: 'Anyone who has felt this passionate rhythm [of tango] running through her veins can never forget it,' said Ranko Fujisawa, the Japanese 'tango queen'. See Marta E. Savigliano, Tango and the Economy of Passion (Boulder: Westview Press, 1995), p. 190.
16. K. Meira Goldberg, 'Border Trespasses: the Gypsy Mask and Carmen Amaya's Flamenco Dance', unpublished PhD dissertation, Temple University, 1995, p. 406.

17. Isabel Laguna, 'Shoji Kojima, "El Gitano Japonés",' El Dia, 26 February $2011<$ http://eldia.es/ gente / 2011-02-26/4-Shoji-Kojima-gitano-japones-flam enco-es-Dios.htm>.

18. Masami Takaba, 'Japoneses apasionados por el Flamenco', 2013 <https://www.youtube.com/watch? $\mathrm{v}=\mathrm{GVusO}-\mathrm{zJp} 2 \mathrm{k}>$.

19. Yolanda van Ede, 'Sounding Contestation, Silent Suppression: Cosmopolitics and Gender in Japanese Flamenco', in Dance Ethnolography and Global Perspectives: Identity, Embodiment, and Culture, ed. L. Dankworth and A. David (Basingstroke: Palgrave, 2014), p. 154-71.

20. Indians have not been much interested in learning Western classical dance or music. Instead, India's numerous performing arts are increasingly incorporating aspects of foreign arts.

21. Guillermo Rodriguez Marín, 'Vicente Escudero, el Flamenco y la India', in India-España Sueño y Realidad: 2000 Años de Relacciones, government publication, Indian Embassy in Spain, 2003, p. 146-54.

22. Miriam Phillips, 'Hopeful Futures and Nostalgic Pasts: Explorations into Kathak and Flamenco Dance Collaborations', in Flamenco on the Global Stage: Historical, Critical and Theoretical Perspectives, ed. K. Meira Goldberg, Ninotchka Devorah Bennahum, and Michelle Heffner Hayes (Jefferson, NC: MacFarland, 2015), p. 42-55, note 10. Sangam (Confluence), a film about interaction between Escudero and Shankar, was to be directed by Jaime Chavarri in 2014, but has not been made. Instead, Torobaka, a collaboration between kathak Akram Khan and flamenco Israel Galvan, the first between two male dancers, toured India under the auspices of the British Council in 2015.

23. Roger Salas, 'Kathak por Buleria', El Pais, 23 October 1985, trans, by author <https://elpais.com/ diario/1985/10/23/cultura/498870011_850215.html>.

24. Phillips, 2015, p. 51.

25. Aoyama, 2015, p. 14

26. Ibid., p 15.

27. Despite the claims to internal similarities, interest issues mostly from the Japanese side. Neither Spanish payos (non-gypsies) or Gitanos learn Japanese traditional dance but butoh is being introduced into Spanish choreographies.

28. Ironically, there is little room for individual freedom in the hierarchal Japanese flamenco studio that demands conformity, discipline, and absolute loyalty to the teacher. See van Ede, 2014, p. 162.

29. Sayoko Yamaguchi, cited in Aoyama, 2015, p. 15.

30. Van Ede, 2014, p. 154.

31. Eriko Arita, 'Mayumi Kagita: a Fusion of Cultures Revealed in Dance', Japan Times, 1 January 2012 $<w w w . j a p a n t i m e s . c o . j p /$ life / 2012 / o1 / o1 / people / afusion-of-cultures-revealed-in-dance/\#.WcXKrdR97-Y>.

32. Goldberg, p. 36.

33. Arita.

34. Van Ede comments on the tremendous cost a Japanese dancer will outlay for a new costume if she is to dance solo at the studio's annual happiokai (van Ede, 2014, p. 162).

35. Goldberg, p. 343-4

36. Ibid., p. 345.

37. Gregory M. Pflugfelder, Cartographies of Desire: Male-Male Sexuality in Japanese Discourse, 1600-1950 (Berkeley: University of California Press, 1999), p. 225. 
38. Emilyn Claid, Yes? No! Maybe: Seductive Ambiguity in Dance (London: Routledge, 2006), p. 182.

39. Goldberg, p. 373-4.

40. Ibid., p. 264.

41. Ibid., p. 237.

42. Hayes, p. 149.

43. Aimee Zink, 'Takarazuka's Crossdressing Starlets', 16 July $2014<w w w . t o f u g u . c o m / j a p a n / t a k a r a$ zuka/>.

44. Mérimée's Carmen appears in many disguises, but never dresses as a man.

45. Imaizumi Fumiko, cited in Ian Buruma, $A$ Japanese Mirror: Heroes and Villains in Japanese Culture (London: Cape, 1984/2012), p. 118.

46. Buruma, p. 121.

47. A kind of ersatz sultry 'Carmen' image of flamenco infiltrates Indian popular culture, as in Aishwarya Rai Bachchan's Bollywood flamenco at the 2013 Femina Miss India Competition $<$ www.youtube. $\mathrm{com} /$ watch? $\mathrm{v}=$ TcoyTCsac- $4>$.

48. Lal's book was republished by India's Publications Division Ministry of Information \& Broadcasting in 2017. 'Even today, there are nomadic groups in Iran, Afghanistan, and Pakistan known as Luri, Nuri or Luli. As opposed to the Roma, however, they speak Beluchi instead of an Indian idiom. Although until recently they, too, travelled around as craftsmen and musicians, their migrations tended to aim east rather than west. It can therefore be disclaimed that today's Luri are identical with those of former times.' See <http: / / rombase.uni-graz.at/cgi-bin/art.cgi? src= data/hist/origin/persia.en.xml>.

49. Phillips, 2013, p. 416.

50. Pallabi Chakravorty suggests that in the process of the post-Independence institutionalizing of India's dances, kathak's history was manipulated, bypassing the contributions of the female nautch dancers and middle-class women revivalists, reducing the Muslim influence, and reinforcing the connection with kathkar storytellers. See Pallabi Chakravorty, 'Dancing into Modernity: Multiple Narratives of India's Kathak Dance', Dance Research Journal, XXXVIII, No. $1 / 2$ (Summer-Winter, 2006), p. 115-36<www.jstor.org/ stable/ 20444667>.

51. 'However, footwork was a later development in both forms, and the various theories on the Gypsy exodus from India agree that it occurred before the fifteenth century; that is, before the footwork element truly developed in kathak. Kathak's footwork advanced between the sixteenth and seventeenth centuries, yet flamenco as a dance form was not even birthed until the eighteenth century. Therefore, the likelihood of footwork being passed from one culture to the next, at least directly, is not viable.' See Phillips, 2013, p. 416.

52. Ibid., p. 417 .
53. Margaret E. Walker, India's Kathak Dance in Historical Perspective (London: Routledge, 2016), p. 134.

54. Ayla Joncheere, 'Kalbeliya Dance from Rajasthan: Invented Gypsy Form or Traditional Snake Charmers' Folk Dance?' Dance Research Journal, XLIX, No. 1 (April 2017), p. 37-53.

55. Dance scholar Kapila Vatsyayan describes earlier instances of Rajasthani tribal dances being performed publicly by men or by both sexes, none danced solely by women. See Traditions of Indian Folk Dance (New Delhi: Indian Book Company, 1976).

56. Joncheere, p. 47.

57. Ayla Joncheere, 'Intangible Inventions: the Kalbeliya Gypsy Dance Form, from its Creation to UNESCO Recognition', Archiv Orientalni, LIII (2015), p. 71-93.

58. Phillips, p. 407-9.

59. Richa Gulati, 'The Fusion of Flamenco Natyam', Little India, 15 November $2006<$ https: / / littleindia.com/ the-fusion-of-flamenco-natyam $>$.

6o. Priyanka Dasgupta, 'When Flamenco Meets Bharatanatyam', Times of India, 3 February $2011<$ https: / / timesofindia.indiatimes.com/life-style/spotlight/ When-Flamenco-meets-Bharatanaty a m / article show / 7354258.cms>.

61. David Fernandez, 'Se pierde en La India', Diario de Sevilla, 4 March $2008<$ www.diariodesevilla.es/ ocio / Romali-pierde-India_o_128387488.html\&\#39; Romalí\&\#39>.

62. Daniel Perez, 'Manuela Carrasco Vuelve Hoy a los Antepasados Flamencos con 'Romalí'"', Lavozdigital, 2 March 2008 <www.lavozdigital.es/cadiz/20080302/ cultura / manuela-carrasco-vuelve-antepasados-2008 0302.html>.

63. Katarzyna Skiba 'Redefining Hybridity in Contemporary Kathak Dance', Przeglad Kulturoznawczy, IV, No. 30 (2016), p. 435-51.

64. Phillips, p. 411-12.

65. Skiba, p. 438-9.

66. Ketu H. Katrak, Contemporary Indian Dance: New Creative Choreography in India and the Diaspora (Basingstroke: Palgrave, 2011), p. 43-4.

67. Purnima Shah, 'Transcending Gender in the Performance of Kathak', Dance Research Journal, XXX, No. 2 (Autumn, 1998), p. 2-17.

68. Chakravorty, p. 130.

69. Prarthana Purkayastha, Indian Modern Dance, Feminism and Transnationalism (Basingstroke: Palgrave, 2014), p. 36.

70. The television drama Bollywood Carmen (2013) adapted the story and opera music without any flamenco influence.

71. Somudra Banerjee, 'The Flamenco Artist of India', The Asian Age, 10 April 2017 <www.asianage.com/life/ art/100417/the-flamenco-artist-of-india.html $>$.

72. Hayes, p. 171. 